\title{
ECHO ACROSS THE OCEAN: SELECTED PROSE OF HAMZAH HUSSIN AND THE HOUSE OF EARTH TRILOGY BY PEARL S. BUCK
}

\author{
(Gema Merentas Lautan: Prosa Terpilih Hamzah Hussin dan \\ Trilogi The House of Earth oleh Pearl S. Buck)
}

\author{
Evgeniya S. Kukushkina \\ zhenya_isaa@mail.ru
}

Department of Philology of Southeast Asia, Korea and Mongolia, Institute of Asian and African Studies, Moscow State University.

Published on: 3 June 2019

To cite: Evgeniya S. Kukushkina. (2019). Echo across the ocean: Selected prose of Hamzah Hussin and The house of earth trilogi by Pearl S. Buck. Malay Literature, 32(1), 93-115.

\begin{abstract}
This paper focuses on the issue of external contacts in early modern Malay literature in the 20th century. It applies historical and comparative methods of research to three renowned novels by the Malay author, Hamzah Hussin, written between 1951 and 1956. This paper aims to trace their possible connection with the famed The House of Earth trilogy (1931-1935) by the American Nobel Prize Laureate, Pearl S. Buck. The results of analysis demonstrate notable correspondences between the respective novels of Hamzah Hussin and Pearl S. Buck on the level of issues raised and storyline. Both sets of novels also share the same central image of house/home, which provides the core development of plot. Additionally, the women characters are found to share commonalities in both sets of novels. It is hoped that this paper prompts future studies on the Occidental influences in Malay authors and literature.
\end{abstract}

Keywords: Malay literature, American prose, novel, Hamzah Hussin, Pearl S. Buck, literary contacts, Occidental influence 


\begin{abstract}
Abstrak
Artikel ini memfokuskan isu hubungan luar kesusasteraan Melayu modern pada awal abad ke-20. Artikel ini memanfaatkan kaedah kesusasteraan bandingan dalam penelitian terhadap tiga novel terkenal penulis Melayu, Hamzah Hussin di antara tahun 1951 dan 1956. Artikel ini bertujuan untuk menjejaki kemungkinan hubungan dengan novel terkenal trilogi The House of Earth (1931-1935) oleh penulis Amerika dan pemenang hadiah nobel, iaitu Pearl S. Buck. Daripada analisis menunjukkan terdapat kaitan antara novel-novel Hamzah Hussin dan Pearl S. Buck tentang isu yang diutarakan dan jalan cerita. Novel kedua-dua penulis ini berkongsi tumpuan imej yang sama, iaitu rumah atau kediaman yang menyediakan asas pembangunan plot. Selain itu, watak wanita dalam novel mereka didapati berkongsi permasalahan yang sama. Diharapkan artikel ini mengundang kajian lanjutan pada masa akan datang terhadap pengaruh oksidental dalam karya penulis dan kesusasteraan Melayu.
\end{abstract}

Kata kunci: Kesusasteraan Melayu, prosa Amerika, novel Hamzah Hussin, Pearl S. Buck, hubungan persuratan, pengaruh oksidental

\title{
INTRODUCTION
}

The significant role of external factors in the development of Malay literature during both the medieval period and 19th century has been not only acknowledged, but rather overestimated for a fairly long period of time. Indeed, Sir Richard O. Winstedt's widely quoted statement about the "rarity of indigenous growth" in Malay literature is a succinct reference on the matter (1969, p. 5). The straightforward evaluations that were typical of early scholars has long been abandoned. Similarly, the idea of "simple [and] static borrowing" has been rejected and replaced with an understanding of cultural interaction being the "dynamic processes of selective appropriation and subsequent adaptation, re-shaping and transfiguration" of foreign elements (Braginsky, 2004, p. 9). However, its extensive presence in traditional Malay belles-lettres has never been scrutinized. On the contrary, when it comes to writings of the 20th and 21 st centuries, the problem of external cultural impact has been somewhat scarcely discussed. This is also true for studies of the relations between early pre-World War Two Malay novels and prose of the Middle East, which are colored by ideas of Islamic reformism. At the very least, this subject is normally touched upon in discussions of prose 
of the 1920s and 1930s. Regarding Western influence on the literature of British Malaya (present-day Malaysia), this topic was only given attention in the 2000s, and definitely merits further scrutiny.

The main reason for this long-term lack of scholarly interest lies in the specific nature of the colonial education system and its marked imprint upon the formation of the intellectual strata in Malaysia. The English-medium education provided mainly to the offspring of aristocratic families resulted in them breaking their connection with their native culture and deprived them of any inclination to participate in the local literary process (Tan, 1986). Conversely, the pioneers of modern Malay literature mainly came from rural schools with a subpar curriculum. Some of them studied in Sultan Idris Training College, which offered a middle-school curriculum for the Malays while, at the same time, intentionally separating them from Western culture. Ungku Maimunah Mohd. Tahir (1994, p. 70) concisely summed up the result of this practice:

Malay literature thus became the preserve of the Malay-educated teachers and journalists. This unpretentious progeny together with its humble background, in turn, defined Malay literature and related activities ... as non-elite cultural forms.

University graduates entered the Malay literary arena later in the 1970s (Sejarah, 2006, p. 334), though this did not instantly progress the situation. The foundation laid by the country's colonial past did not stimulate the Malay writers to aspire for cross-cultural discoveries. It appears only too logical that researchers' attempts to trace any Occidental influence in the "non-elite" artistic endeavors of the humble "Malay-educated teachers and journalists" proved somewhat unpromising. However, striking findings were uncovered from time to time. W.R. Roff (1974) concluded that the first Malay novel appeared in the form of a detective story and imitated the writing style of the American Nick Carter-Killmaster series. Additionally, several other early adventure novels by Syed Shaikh al-Hady were inspired by the prose of French authors, Eugène Sue and Pierre Alexis Ponson du Terrail (Abdul Rahman, 1987, pp. 53-59; Mohamad Saleeh \& Mohamad Mokhtar, 2009, pp. 19-29). These discoveries led researchers to suggest the existence of French prototypes for several serious reformist novels of the 1920s as well as several later pre-World War Two writings in British Malaya (Abdul Rahman, 1987, pp. 59-65). The following decades witnessed 
the emergence of numerous interesting contributions that shed new light on the history of Malay literature and its relations with Western culture. The pioneering works of $\mathrm{H}$. Warnk on the influence of translations on Malay writings from the 1850 s to 1950 s prove that despite the scarcity of translated fiction published in British Malaya during this time, it managed to spark a wave of responses and imitations (2007; 2011). Notable results were achieved by Nurul Farhana in her studies of the interpretation of Shakespeare in bangsawan theatre $(2009 ; 2012)$. Translations of selected plays of Shakespeare into the Malay language proved to have left their imprint on early local dramaturgy (Kukushkina, 2017). As a result, modern Malay literature gradually revealed its intercultural contacts, which turned out to play a significant role in the early stages of its formation in the first decades of the $20^{\text {th }}$ century when the number of educated Malays was minimal.

\section{"A BOOKWORM" DISCOVERS FOREIGN LITERATURE: HAMZAH HUSSIN AND HIS BACKGROUND}

Among the early Malay literary representatives who were "unpretentious progeny with humble background" (Ungku Maimunah, 1994), there were those who had more chances to open new horizons. First of all, in contrast to the average Malay, they were city dwellers. Being born into a wealthy family was an additional benefit that allowed a young Malay man to attend an English-medium school. Material wellbeing also provided the possibility to set aside some time for self-cultivation. Personal qualities such as inquisitiveness and perseverance also helped in making use of every opportunity to gain knowledge.

All these life conditions and personality traits were inherent in Hamzah Abdul Majid bin Hussin (1927-2007), who remains known in the history of modern Malay literature simply as Hamzah Hussin. He is best remembered as one of the founders of Angkatan Sasterawan 50 (ASAS '50) and one of the main participants of a fiery dispute on the mission of literature. The defeat of Hamzah and his group as upholders of "Art for Art's Sake" led to their departure from ASAS '50, though this did not diminish his contribution to the philosophy of creativity of his time. Besides, his novels and short stories appear to be rather remarkable due to their traces of foreign influence. Hamzah certainly had better opportunities to become acquainted with world writings than many of his contemporaries.

Hamzah's formative years and early writing career occurred in Singapore, 
which was then a major cosmopolitan port and the main cultural center of British Malaya. He came from a large yet relatively wealthy family that was able to provide education for their children. He first attended a Malay primary school, followed by an English junior secondary school. The event of World War Two prevented him to getting his certificate and, so, he continued the next 4 years of his education in a religious school (Mohd. Thani et al., 1988, p. 273; Mohamad Raezi, 1994, pp. 14-15). Through his education, Hamzah was exposed to "all three main educational types that existed in the country at the time" and, consequently, "to a wider impact from outside". He combined his good command of English with profound knowledge of religious matters (Athi Sivan, 1997, p. 30). All these incidences placed a gifted youth as him in a special position.

Researchers have precisely identified the significant contributions of those who mastered both the English and Arab languages in modern Malay literature. These international languages made the outside world more accessible to Malay native speakers. Before World War Two, the groundbreaking task of developing Malay literature and mastering new genres was espoused by authors who were brought up in the Middle Eastern Muslim tradition. After World War Two, this pioneering role was passed to those who mastered English as their first foreign language of communication (Tan, 1984, p. 110). Hamzah began his creative path right in the middle of the 20th century, having both sources of knowledge at his disposal.

Hamzah's family was also naturally "literature-friendly". His father was a publisher, bookseller and writer himself, though his publishing and writing interests were of the traditional kind (Hamzah, 1997, pp. 89, 98; Mohamad Raezi, 1994, p. 14). Meanwhile, Hamzah himself sought to master the genre of the Malay novel, which was still fairly new at that time. His acquaintance with world literature began in his youth when he assisted his father in the bookshop and avidly read everything he came across: cartoons, magazines, novels and science editions (Hamzah, 1997, p. 98). In his generation, Hamzah belonged to the few young "bookworms" (ulat buku) who used foreign writings as a tool "to connect the world of Singapore and Malay Peninsular to Indonesia and the West" (Muhammad, 1981, p. 4).

Later, as a journalist, Hamzah carried on this mission of modernizing Malay literature with even greater vigor. In his columns and articles, he "initiated the Malay world into international literature, Occidental as well as Oriental. He was able to discuss Shakespeare's oeuvre and to elaborate 
on such figures... as Webster, Ford, Turner, Ben Johnson and others" (Athi Sivan, 1997, p. 32). However, among the authors preferred by Hamzah, three were mentioned most frequently: Pearl S. Buck, Ernest Hemingway and John Steinbeck (Athi Sivan, 1997, p. 32; Hamzah, 1997, pp. 90, 98; Mohamad Raezi, 1994, p. 25; Mohd. Thani et al., 1988, p. 274).

Each of the three authors mentioned above triggers associations with certain features of Hamzah's writing. However, resemblances between his novels and the prose of Pearl S. Buck (1892-1973) deserve special attention. Her name appears almost invariably in discussions of Hamzah's reading preferences. This is not altogether surprising, considering that in his youth, he witnessed the height of Pearl S. Buck's fame, including her winning both the Pulitzer Prize (1932) and Nobel Prize (1938).

Hamzah's interest towards foreign literature in general and the prose of Pearl S. Buck (Buck) in particular is clearly evident in his three most remarkable novels, namely Rumah Itu Dunia Aku [This House Is My World] (1951), Pemburu Pulang ke Rumah [Hunter Gets Back Home] (1952) and Rumah Kosong [Empty House] (1956). The second novel is a sequel to the first. While the characters of Rumah Kosong have no formal connection with those described in Rumah Itu Dunia Aku and Pemburu Pulang ke Rumah, it is also unlikely that it is a stand-alone novel. The Malay titles of these three novels are promptly linked by the central image of rumah (house/home).

If there were samples of Malay literary series before Hamzah, they must have failed to gain prominence. Even though prior to World War Two, there did exist detective and adventure writings by Muhammad bin Muhammad Said as well as Syed Shaikh al-Hady, they were either too alien for serious prose or failed to attract a wide audience. It seems more plausible that Hamzah was inspired by foreign writers of the genre such as Jean Webster and Ford Madox Ford, both of them were familiar to him. However, it is even more likely that he was inspired by the celebrated "Chinese" triptych by Buck, comprising The Good Earth (1931), Sons (1933) and A House Divided (1935). Even the titles of their respective works seem to bear similarity: Buck speaks of A House Divided, while Hamzah speaks of Rumah Kosong (Empty House). Besides that, Buck's trilogy is titled The House of Earth, which exploits the image of house/home and is also most significant in Hamzah's three novels.

The presence of this central symbolic image, as if stitching together a sequence of novels, is also a common feature in the Malay and American novels of this discussion. For Buck, this symbol is earth - a plot of land 
used to make a living for a household - while for Hamzah, it is the house/ home. These two concepts are different, yet still inseparable and connected by a notion of kin and family seat. The type of narration built around one symbolic leitmotiv was a new concept in early modern Malay literature, just as a trilogy was then a new literary phenomenon.

The two triptychs also demonstrate an evident resemblance in the focal points of their storylines. A big family falls apart after being destroyed by growing repugnance between its members. Some of them get torn off their roots, that is, their earth. Conflict between the older and younger generations make the latter rebel and leave their ancestral home. Buck portrays "a house divided" by its inhabitants, who are no longer nourished by loyalty to each other. Similarly, Hamzah leaves the family house completely empty and abandoned.

\section{TWO CHRONICLES OF FAMILY DISCORD: THE GOOD EARTH AND RUMAH ITU DUNIA AKU}

Buck, who spent many years of her life in China, relates the story of several generations of the Wang family. Through daily drudgery, the family head, Wang Lung, and his wife, O-Lan, progressed from poverty to wealth, overcoming all kinds of hardship and cultivating their land. Decades later, and now a rich landlord, old Wang Lung still reminisces about his land - of the earth - which serves as the source and meaning of his existence. His sons readily use the fruits of their father's labor, but the lives they live are vastly different from his. The first and most famous part of the trilogy, The Good Earth, ends with a telling episode. Walking in the fields with his sons, Wang Lung overhears a conversation between them about their plan to sell the land. In response to their father's resentment, they assure him that they do not intend to get rid of the family land. However, when Wang Lung stands with his back to his sons, tearfully clenching a fistful of warm earth, his sons exchange glances and slyly smile at each other (Buck, 1947, p. 293). They do not care much for the land and, later, after their father's death, they gradually destroy their traditional course of life. Over time, the family stops being a unit of people near and dear to each other and, in the end, even the youngest son leaves the house, filled with mutual estrangement.

Family decay of the same kind is described in Hamzah's novels, though it happens not only spiritually but literally. As the story progresses from one novel to another, a big clan dies out. Among Hamzah's three novels, 
the most impressive is the first, titled Rumah Itu Dunia Aku [This House Is My World], the 1958 edition bore the title Anak Gundik [Concubine's Child] (Sejarah, 2006, p. 527). Its heroine, a young and beautiful maid named Lin, is the daughter of a woman who spent her entire life working for a rich household. After her death, Lin learns that she was fathered by her master, who also dies soon after. Although Lin has to endure a great deal of abuse, she continues to serve in the house because it embodies the whole world for her. Most of its inhabitants are arrogant, cruel and greedy. The eldest son, a heavy built and violent wastrel, goes as far as coveting Lin. Notwithstanding constant harassment and slander, Lin never once thinks about leaving the house. Just as the characters of Buck, who are always busy on their land, Lin is busy every moment in the house.

Lin's attachment to the house is very much akin to the feelings nourished by Wang Lung towards the earth. For Wang Lung, only dire need could force him to sell his land. To him and his wife, "this earth... formed their home and fed their bodies" (Buck, 1947, p. 28). He often reminisces about his younger days, when he was simply known as Wang The Farmer. Now, in his older days and already known as Wang The Rich Man, he still tries to convince his sons, "It's the end of a family - when they begin to sell the land... Out of the land we came and into it we must go" (Buck, 1947, pp. 292-293). After Wang Lung's death, a Confucian scholar writes on his tablet: "Wang Lung, whose riches of body and soul were of the earth" (Buck, 1951, p. 47). If for Wang Lung the center and pillar of the Universe is the earth, for Lin it is the house. This idea is formulated by Lin's half-sister: "Bagiku Lin, rumah ini ialah duniaku, begitu juga dengan dirimu" ["For me, Lin, this house is my world, just like for you"] (Hamzah, 1989, p. 9). Even though she suffers injustice after the death of her father, Lin begs her abusers to allow her to stay in the house, where she faces nothing but new insults and even danger:

Sekiranya saya disuruh keluar dari rumah ini, saya akan keluar tetapi saya lebih suka kalau saya diizinkan tinggal di sini selamalamanya... Sifat saya sebagai seorang orang gaji kerana bagi saya rumah ini ialah satunya tempat menumpang teduh di kala hujan dan panas.

[If I am told to leave this house, I'll go, but it would be after my heart if I were allowed to remain here for good... For me as a servant this 
house is the only place to take refuge from rain and heat.]

(Hamzah, 1989, p. 32).

At the end of the story, Lin learns that the debauched eldest son has sold the house. She is dumbstruck by the news, just as Wang Lung is dumbstruck upon hearing his sons' conversation about selling the land. Lin says, " $A k u$ tersentak... Bagiku Mahmud bukan sahaja telah menjual sebuah rumah, tetapi juga telah menjual duniaku" ["I was taken aback... For me, Mahmud sold not just the house, he sold my world") (Hamzah, 1989, p. 66).

In both the American and Malay novels, the plot develops in the same direction, which is towards family disintegration. The resemblance, however, does not stop here. Within the two stories, we can mark some significant coincidences in every part.

The Good Earth comes to an alarming denouement. The main character, Wang Lung, is growing old and lonely. His wife has long been dead, and only one loving soul who remains by his side is his young concubine, Pear Blossom. One of his sons is a man of pleasure, while another is a shrewd merchant; to them, the land is merely a source of income. His third son even rebels and flees from home. The family eventually disintegrates. Such an ending prepares for the subsequent "centrifugal" course of events that culminates in A House Divided.

Hamzah ends his first novel with an even greater tension, that is, resolving family conflict with a tragedy. Out of the five children of the prosperous Syed Ahmad, only two remain alive; both his children leave home and firmly intent to never return. His only daughter, Zainab, fails to find happiness in her marriage and dies in childbirth. One of his three sons, Mohsin, leaves for Java after being unable to stand the hostile atmosphere in the house and trying to cure his lovesickness. Mahmud is the sleazy son who squanders the family fortune, ruins Lin, seduces the fiancée of his brother, Hasni, and sells the house to get money. The youngest son, Hasni, is unable bear the betrayal of his beloved. Seized by his hatred for all women in the world, he goes mad. In a fit of madness, he fatally wounds Lin when she seeks comfort from him after she was raped by Mahmud. Having wounded her, Hasni commits suicide and Mahmud flees. Thus, both The Good Earth and Rumah Itu Dunia Aku end with an acute family crisis. In the American novel, it is parting and estrangement, while in the Malay novel, it includes the death of family members.

If we scrutinize the storylines of certain characters, we additionally 
come across some important analogies. The third son of Wang Lung and the second son of Syed Ahmad, in the respective novels of Buck and Hamzah, are driven by very similar motives when they leave home. First, their families are equally plagued by discord, which makes the atmosphere hardly bearable. The patriarch of the Chinese family grieves at the sight of hostility between his children, who do not trust or respect one another:

... when the two wives hated each other, their hatred spread to the men also and the courts of the two were full of anger and Wang Lung groaned because there was no peace in his house.

(Buck, 1947, p. 274)

The situation in the household where Lin works as a servant is no better. Immediately after their father's death, the children become engaged in an ugly battle over inheritance. Witnessing this, Mohsin declares his intention to leave:

"Sebenarnya aku benci melihat kau semua dengan tamakmu lebihlebih lagi kerana sangsi di antara satu sama lain takut harta-harta itu akan dibolot oleh seorang sahaja"

["Frankly I loath to see you all with your greed and, above all, your suspicion to each other because of your fear that the property will be embezzled by just one of you"]

(Hamzah, 1989, p. 30)

Another reason that drives both young men far away from home is romantic heartbreak. In The Good Earth, the third son of Wang Lung falls in love with his father's concubine, Pear Blossom. However, Pear Blossom only attracts the attention of Wang Lung himself, and quite unexpectedly responds to his tender feelings. When the son finds out that his father has settled her in his chambers, he disappears from home the next morning. In Rumah Itu Dunia Aku, the same disappointment causes Mohsin to flee away from home. He has long been in love with the beautiful Lin, but cannot be with her. From the very beginning, they are separated by social disparity. Moreover, Lin harbors feelings for his youngest brother, Hasni. Ultimately, Mohsin's last hope of being with Lin vanishes when his father recognizes Lin as his daughter on his deathbed, attesting that Lin and Mohsin are indeed 
sister and brother. Mohsin then decides to leave the house, just as the third son of Wang Lung leaves his family seat.

In the two novels, we not only find resembling basic lines of plot, but also very similar elements of narration. For example, the quiet and tender Pear Blossom, the last love of Wang Lung, harbors such hatred for younger men that it perplexes her master. She speaks of it whenever Wang Lung complains that he is far too old for her: "Young men are not kind - they are only fierce" (Buck, 1947, p. 280). She goes on saying, "I am filled with loathing and I hate them all. I hate all young men" (Buck, 1947, p. 287). Pear Blossom never tells Wang Lung about her reason for such horror and disgust; he can only guess about the sufferings that once befell her.

Pear Blossom's feelings mirror the emotions of Hasni, the third son of Syed Ahmad in Hamzah's novel. He is unable to find peace after the betrayal of his fiancée, Sharifah Mahani.

"Rupa-rupanya Mahani belot, dia cinta kepada kawanku yang lain pula... Kini aku tidak percaya lagi pada cinta. Aku tidak percaya pada perempuan lagi... Aku benci perempuan. Seтua perempuan penipu"

["It looks that Mahani has betrayed me, she fell in love with one of my friends", Hasni tells Lin before adding, "Now I no longer believe in love. I do not believe women any longer... I hate women. All of them are cheaters"]

(Hamzah, 1989, p. 60)

His disappointment causes him to abhor every woman, including the kind and loving Lin. When she tells him that Mahani fled not with a friend of Hasni, but with the immoral Mahmud, Hasni cannot stand the blow, goes insane and fatally injures Lin.

\section{TWO CHRONICLES OF RUNAWAYS: SONS AND PEMBURU PULANG KE RUMAH}

The respective sequels to the first novels of Buck and Hamzah also demonstrate parallels, though at first glance, they do not seem too identical to each other. However, the basic plots of Sons and Pemburu Pulang ke Rumah [Hunter Gets Back Home] have many elements in common. 
First of all, both novels relate the stories of runaways. In Buck's novel, it is the third son of Wang Lung, who has displayed an inclination towards the military since his early youth and caused the disapproval of his father. After he loses hope that Pear Blossom will reciprocate his love, he disappears from home. He joins a detachment of one of local chieftains and makes a meteoric career. In Hamzah's novel, the second brother, Mohsin, is also heartbroken and heads for Java, where he gets married. Shortly afterwards, he learns of the deaths of Lin and Hasni and decides to return home and seek vengeance himself on Mahmud and Sharifah Mahani, both of whom are culpable for the tragedy.

According to Hamzah, initially he did not intend to write the second novel. However, the grave denouement of Rumah Itu Dunia Aku made readers indignant. Traditional and early modern Malay literature mostly comprised happy endings or, at the very least, infliction of severe punishment for wrongdoers. Hamzah himself had to listen to the demands of his audience and eventually wrote the sequel (1997, pp. 100-101). The trilogy by Buck may have at least provided him with some important milestones.

The central characters of Sons and Pemburu Pulang ke Rumah not only live the same kind of vagabond lifestyle, but are depicted with the similar symbolism of predatory instinct, comprising hunting and chasing the victim. In Buck's triptych, this symbolism first appears in the ending of The Good Earth, when Wang the Third visits his father upon hearing that the old man has taken Pear Blossom to his courts:

Then suddenly there was his youngest son standing before him, sprung out of the darkness of the court, and no one had seen him enter. But he stood there in some strange crouching way, and... Wang Lung was reminded of a panther he had once seen the men of the village bring in from the hills..., and the beast was tied but he crouched for a spring, and his eyes gleamed, and the lad's eyes gleamed...

(Buck, 1947, p. 284)

The youth displays distinct beastly features. In Sons, he becomes known as a warlord, Wang the Tiger, who constantly attacks his enemies by turning them into victims. One instance is when he traps and murders his rival commander, who is known as Leopard.

This motif of hunting, that is, of a predatory chase, is equally important in the second novel by Hamzah, as evident in its title, Pemburu Pulang ke 
Rumah. The hunter here is Mohsin, who returns from Java to trace Mahmud and Sharifah Mahani and make them answer for the deaths of Lin and Hasni. Mohsin truly believes himself to be a hunter and openly states so in his letters to his wife, Trimutri, whom he leaves in Java:

\begin{abstract}
"Aku terpaksa keluar dari rumah ini, aku terpaksa mengundur diri dari dunia kita. Aku keluar dari rumah ini sifatku sebagai seorang pemburu - memburu pembalasan"

["I have to quit this house, I have to withdraw from our world. I am leaving this house as a hunter - hunting my revenge"]
\end{abstract}

(Hamzah, 1989, p. 80)

Gnawed by his vindictive plans and rejecting all human emotions as long as his mission remains unresolved, Mohsin acquires beastly traits, just as Wang the Tiger. Trimutri becomes clearly aware of this:

“... $[A]$ ku terpaksa menyatakan bahawa kanda bukan lagi manusia bagiku... [A]ku memandang manusia adalah berhak dipanggil manusia apabila hanya kebajikan sahaja yang jadi hidupnya, biarlah orang lain menanam perasaan dengki terhadapnya, sebaliknya bagi orang lain itu dia hanya dapat memberikan kasihan..."

[“...I have to tell you, that you are no longer human for me... To my mind a human only has the right to be called a human if only goodness constitutes his life, let the others bear grudge against him, he can only response with sympathy..."]

(Hamzah, 1989, p. 82)

Both these respective characters of Buck and Hamzah are implacable and belligerent; they resort to running from their misfortunes and inevitably bringing them upon others. Wang the Tiger grows out of his "reedy slender youth" (Buck, 1947, p. 275) into a man who is "tall and black and strange and his eyes shining like tiger's eyes" (Buck, 1951, p. 80). He warps many lives in his path. His tender nephew, the son of the sybaritic Wang the Eldest, commits suicide after Wang the Tiger takes him into his detachment and the boy fails to endure the hardships of military life. Having killed his rival, Leopard, Wang the Tiger begins to collect toll from the local people in the same cruel manner as his predecessor. He unhesitatingly puts his wife to death when he learns of her treason. During the period of famine, for the 
sake of discipline, he becomes ruthless with his hungry soldiers. His harsh and sometimes merciless single-mindedness helps propel him to a high military position and win battles. Nevertheless, there is no one to inherit his victorious traditions and fighting skills. Similar to himself many years ago, his own son does not bend to his parental will. After Wang the Tiger sends him to military school, he returns four years later wearing a uniform of the revolutionary army that fights local rulers and chieftains such as Wang the Tiger himself. The old warlord is deeply shocked, though his son has no wish to fight him personally: "Wang the Tiger sat still and over him rolled the bitterness of his whole life. He... looked at his son and saw there a man he did not know" (Buck, 1951, p. 450). Now, he could only clutch onto his renowned firmness and endurance: "After all, he would not weep" (Buck, 1951, p. 451). Thus, Buck leaves her character on the peak of acute disappointment.

Mohsin, in Hamzah's second novel, Pemburu Pulang ke Rumah, experiences the same kind of bitterness. Dreaming solely of revenge and forgetting about love and mercy, he writes to Trimutri, "Aku sudah bersumpah..., aku tidak akan kembali menghadap dikau sebelum darahku sebagai seorang pemburu dapat kupuaskan ["I swear..., I will never come back to you again before I can satisfy my blood of a hunter"] (Hamzah, 1989, p. 115). In the end, his words come true; he never returns to Trimutri because she dies of grief. Further, even this great sacrifice for the sake of revenge is in vain. Just as Wang the Tiger, Mohsin eventually finds his mission to be meaningless. It is not him who is destined to do justice upon Mahmud, but his old friend, Salim, who once was a sweetheart of Sharifah Mahani before her betrothal to Hasni. Salim emerges in the story quite unexpectedly to forgive and marry his repenting beloved, and to kill Mahmud. Mohsin could only reconcile himself with the thought that someone else has completed his mission, but drops dead upon hearing that it is an old friend of his who will stand trial together with Sharifah Mahani.

As we can see, the second pair of novels also demonstrate certain correspondences that cannot be simply neglected. Two heroes, similar in their approach to life, come to similar disappointment. For Wang the Tiger, it is only bitterness and emptiness, while for Mohsin, it includes death.

There is yet another link between Sons and Pemburu Pulang ke Rumah. A considerable part of Hamzah's novel is written in the form of letters exchanged between characters. This was quite common in early Malay novels because letters did not take much of their narrative space. Unlike 
his pre-World War Two predecessors, some of Hamzah's entire chapters solely comprises exchanges of letters or diary entries. In this respect, he proudly thought of himself as a pioneer in introducing this literary technique (Hamzah, 1997, p. 100). However, while the modern epistolary and diary genres were not quite developed in the Malay literature of the time, Western writers already had a rich experience of the genres, and this was definitely known to Hamzah.

One of the most important writers of the epistolary novel genre was Jean Webster, her best known work being Daddy-Long-Legs (1912). Her work was known to secondary school students in British Malaya. Before World War Two, one Malay writer even presented a direct reworking of Daddy-Long-Legs in his short story, Hindun, A Poor Student (Hindun Sa-orang Murid Yang Miskin) (Ariffin, 1964). This novel definitely must have caught Hamzah's attention. Still, its topics and problematics do not appear too close to his interests. It seems more plausible that the idea of using correspondences and diary entries extensively in Pemburu Pulang ke Rumah must have been inspired again by Buck, though this time not by The House of Earth trilogy, but by her first serious literary attempt, which is East Wind: West Wind (1930). The plot of this novel is constructed upon letters written by a young Chinese girl to her foreign friend. Keeping in mind that the American writer was one of Hamzah's favorite authors, it appears possible to suggest a link here as well.

\section{TWO HOUSES AND THEIR INHABITANTS: THE HOUSE DIVIDED AND RUMAH KOSONG}

The remaining third pair of novels-The House Divided by Buck and Rumah Kosong [Empty House] by Hamzah-requires caution. While The House Divided was undoubtedly created as the final part of the trilogy, Rumah Kosong is traditionally viewed as a stand-alone novel (Athi Sivan, 1997, p. 76). Hamzah himself also did not establish any distinct connection between this novel and the previous two (1997, p. 100). Nevertheless, the three novels demonstrate a striking continuity of the central image of the home/ house. Rumah Kosong does not comprise any characters from Rumah Itu Dunia Aku and Pemburu Pulang ke Rumah, and even though the concept of the home/house is still present, it continues to evoke mostly gloomy associations. This image undergoes a certain evolution from one novel to another. Rumah Itu Dunia Aku is all-powerful and holds captive the main 
heroine, Lin, who is unable and unwilling to leave the house in which she suffers. In the second novel, Pemburu Pulang ke Rumah, the main character, Mohsin, attempts to break free from the ominous house, but still returns to it in order to seek revenge. Only the heroine of Rumah Kosong truly manages to escape from this abode of dark feelings. Her parting with an old family seat symbolizes the beginning of a new life. The image of a somber house binds the three novels together in such a way that the third novel appears as a natural continuation of the previous two, even if it was not intended by Hamzah. On that ground, a comparison between Rumah Kosong by Hamzah and $A$ House Divided by Buck seems appropriate, especially since we find interesting commonalities.

In Hamzah's Rumah Kosong, 35 year-old spinster, Wan, lives in an old house alone after the death of her well-to-do parents. Although her social position differs greatly from that of Lin, Wan also considers the house as her whole world. From the very beginning, the writer equates Wan's empty soul with her house, which is almost uninhabited: "Esoknya kosong sebagaimana kosongnya rumahnya yang besar ini yang didiami oleh seorang dan orang gajinya" ["Tomorrow is going to be empty, like this big house of hers, where she lives alone with her servants"] (Hamzah, 1997, p. 140). Wan spends all her time indoors being immersed in gloomy reminiscences and dreams. Her servant, Damin, can feel Wan's inner longing and even dares to try and have his way with her after poisoning his pregnant wife. However, this gruesome crime does not help him achieve his goal. There also resides a guest in the house, a young artist named Dzulkifli, who saves Wan from Damin's advances, declares his love for her and takes her away from the odious place forever. Wan's soul is again bursting with feelings and she can no longer stand living in "rumah kosong ini" [this empty house], prompting the loving couple to leave it immediately.

At first glance, this story does not have anything in common with the events depicted in Buck's A House Divided. However, if we do not look at each event as a separate episode, but as the whole storyline, we shall see that the American trilogy possibly left its imprint on Hamzah's novel.

First of all, the plot of $A$ House Divided is strongly colored by intrigue and melodrama (Bezruk, 1997, p. 13). Wang Yuan, the son of Wang the Tiger, faces recurring intrigue. Having abandoned his birth place, he has to withstand ruses aimed to drive him back home to get married. Later, his former beloved of revolutionary convictions informs on him to the authorities to requite him for their parting. When the threat of detention forces Wang Yuan to flee to 
America, he has to resist attempts to convert into Christianity. Regarding the melodramatic elements, the novel is definitely rich in this respect. The romantic lines of the main character is imbued with unexpected turns: he enters into a romantic relationship with a daughter of his American friend and, upon his return home, with a local girl who is a foundling adopted by his family. In the end, the latter becomes Wang Yuan's wife.

In Rumah Kosong, Hamzah shows no less inclination to intrigue and melodrama. The guileful Damin tries to win Wan's favor, even at the expense of murder, and seeks to discredit his rival, Dzulkifli, in her eyes. The style is strongly colored by melodramatic parlance:

\begin{abstract}
Sekarang jiwanya ditimpa rasa berubah, Wan memang sedar bahawa sekarang pintu hayatnya telah terbuka, dan merangkak ke dalam dewi asmara perlahan demi perlahan, sehingga mendirikan sebuah istana yang suci di tengah-tengah puri hatinya.
\end{abstract}

[From now on her soul was captured by another feeling, Wan really realized that the doors of her life have been thrown open, and goddess of love was sneaking inside little by little, erecting a holy palace within the abode of her heart]

(Hamzah, 1997, p. 205)

Hamzah uses these words to describe the way Wan feels soon after her encounter with Dzulkifli. Rumah Kosong is almost exclusively devoted to the development of this love story.

The endings of both novels are critically important for comparison. After his return from America, Wang Yuan has to settle a great amount of problems in the country, which has since changed extensively:

Immersing the character into the turbulence of political events upon his return to China, the writer leaves him at parting of the ways: he cannot find shelter in the old house of his grandfather, because he has outgrown its limitations... The author leaves her reader with an 'open denouement'...

(Bezruk, 1997, p. 13)

The death of his father, Wang the Tiger, marks a turning point in Wang Yuan's life; here lies his actual parting of ways. On the one hand, he is tortured by anxiety and fear. Standing on the threshold of his old house, he 
ponders, “...[W]ho could say, what days lie ahead? There was no more surety in these days - not even surety of the earth... He was afraid" (Buck, 1935, pp. 371-372). On the other hand, his wanderings have made him stronger and his beloved, Mei-ling, who has just reciprocated his feelings, stands beside him. His inner turmoil calms down and is replaced with happiness and the resoluteness to overcome hardships:

His heart began to mount and mount until his body was full of all his beating heart. He laughed into the night. What was it he had feared a little while ago? "We two", - he said - "we two - we need not be afraid of anything"

(Buck, 1935, p. 375)

Returning to Hamzah's Rumah Kosong, we find a strikingly similar ending. The author makes the scene structurally very close to that of A House Divided. The main difference is that Buck mostly describes the feelings of her male character, while Hamzah tells the story from the women character's point of view. Wang Yuan was certain that after his quarrel with Mei-ling, he did expect her to reciprocate his love. However, it turns out that she does love him. Hamzah's heroine, Wan, also believes that she is unable to nourish any hope, especially after her beloved has declared his intention to leave her house. However, Dzulkifli explains to her that he was driven to save her from the evil Damin not by pity, but by his tender feelings for her; he saw that the emptiness of Wan's soul was not real and fell in love with her.

The final scenes of both novels take place in the threshold of an old house and their concluding lines express joy and confident expectations of a better future. Wang Yuan leaves behind his fears, though he is still burdened by many problems. Wan goes through a similar experience when she and Dzulkifli are about to leave the house and he shows her his picture, explaining its meaning:

Dzulkifli membukakan tabir yang melindungi lukisannya itu.

Terlihat oleh Wan hanyalah coretan warna warni yang tidak melukiskan suatu lembaga pun.

Menghilangkan keraguan Wan, maka Dzulkifli sambil meraih pinggang Wan lalu berkata: "Itulah hidup. Warna-warna itu adalah jenis dan peribadi manusia, yang nampaknya tidak punya tujuan dalam hidup" 
[Dzulkifli took off the cover that concealed his painting.

Wan saw only multicolored lines that did not form a single silhouette. To assuage Wan's doubts, catching her round the middle Dzulkifli said: 'Here is life. There is a type and a character of someone who is unlikely to have any goal in life']

(Hamzah, 1998, p. 219)

Before meeting the young artist, Wan lived aimlessly in her dim formless dreams. Dzulkifli takes responsibility for her, offering her a life that makes sense instead of an existence made of a blurred, shapeless constellation of colors. Just as Wang Yuan and Mei-ling, Wan and Dzulkifli start a new life together; although it is definitely not easy, they are nonetheless full of readiness to overcome all its pains.

\section{TWO LIVES OF SACRIFICE: WOMEN CHARACTERS OF PEARL S. BUCK AND HAMZAH HUSSIN}

In terms of the storyline as well as specific episodes, the three novels by Hamzah seem to echo particular aspects of Buck's writing. They also demonstrate a considerable resemblance of the problems raised by Buck, who is an acknowledged propagator of feminist ideas: "In Buck's work, from the early 1930s until the late 1960s we see a strong attention to women's status, including both their oppression and their potential strength. ...Buck and her colleagues in the literary milieu of the 1930s, 1940s and 1950s... helped prepare the ground for modern feminism" (Shaffer, 2016, p. 1). Women's themes are so explicitly evident in her prose that it has become a distinctive subject of research based on her "Chinese" novels (Gao, 2000).

Similar to Buck, Hamzah did not remain indifferent to women's issues and often pushed them forward in his prose; this is believed to be one of the reasons for his popularity (Mohamad Raezi, 1994, p. 30). Women's issues in Hamzah's works have become a subject of scrutiny in Malaysia (Siti Mariam, 2010; Elizatul Natasyah \& Mohd. Zariat, 2017). The women characters are present among the most prominent figures appearing in his novels. Hamzah tends to portray traditional virtues as well as more modern and enlightened attitudes that were proper to womenfolk of the time. Villainous women characters are also given their place in his writing. The diversity of women profiles in Hamzah's novels again reminds us of Buck, who created "a wide array of women characters with different beliefs, personalities, and social 
and economic backgrounds" (Gao, 2000, p. 10). Besides, there are distinct correspondences between particular women characters of the two authors. Such parity is particularly striking in the case of Lin from Rumah Itu Dunia $A k u$ by Hamzah and O-Lan, the wife of Wang Lung in The Good Earth by Buck - the two most important heroines in respective novels.

Both Lin and O-Lan are equally submissive, reticent and humble; they both also work tirelessly and selflessly, being totally loyal to those around them. At first glance, both may look too unpretentious, even primitive, but in fact both have their own inner life and dignity. Lin and O-Lan are so dutiful and avoid self-expression to the extent that it seems natural to classify them as blunt and dull. Buck transmits this opinion of O-Lan through her husband, Wang Lung, to whom she is just a "dull and faithful creature who had labored all her life at tasks for which she won no reward..." (Buck, 1947, p. 121). This thought comes to Wang Lung when he finds a small bundle full of jewels between his wife's breasts. O-Lan discovered a hiding in a rich house that they happened to enter during the turmoil in the southern city where they had to shift temporarily in times of bad harvest. This treasure becomes the foundation of family wealth that starts growing rapidly. Wang Lung is astonished by the fact that the "dull" O-Lan managed to find a hiding, or that she is actually not as stupid as he prefers to think. Far too often, the ever-silent O-Lan sees through every feeling and thought of her husband, though he looks much more superior to her intellectually.

The same can be said about Lin, the servant girl in Hamzah's novel, Rumah Itu Dunia Aku. National Laureate, S. Osman Kelantan, who edited the collection of Hamzah's novels, reserved a few pages in his foreword for his reasoning about Lin's simple-mindedness, calling her gambaran kebodohan dan kepandiran [a picture of stupidity and bluntness] (Othman, 1998, p. xii). This evaluation does not coincide with the way Hamzah himself viewed his heroine. Lin appears capable of giving a sensible answer to any question posed to her. For example, when the husband of her master's daughter begins flirting with her, she tries to protect herself from his advances in a polite and patient manner. To his open proposal to become his second wife and live an easy and pampered life, she replies:

"Sekiranya lelaki mengahwini saya, hendaknya bukanlah kerana rupa tetapi kerana budi dan hati saya. Dan kalau pula saya kahwin, suami saya ini tidak saya kira tentang cantik atau kayanya, tetapi saya pandang dari segi budinya." 
["If some man ever married me, then it would be good if it was not for my appearance, but for my nature and my heart. And if I am ever to get married, I will not judge my husband by his handsomeness or wealth, but I will look at his nature"]

(Hamzah, 1998, p. 14)

The young man acknowledges that Lin's answers "selalu benar berisi sindiran atau falsafah" [are always full of tease or philosophy]. Both O-Lan and Lin possess an outstanding inner strength that allows them to endure hardships. Despite this, their strength has its limits. O-Lan succumbs to the illness she acquires from excessive labor and subtly grieves at her husband's decision to take a concubine. Lin falls victim to murder. However steadfast they both are, they are still unable to claim their happiness. The tragic ends of the main women characters again brings together the writings of Hamzah and Buck.

\section{CONCLUSION}

As Tan Chin Kwang rightly points out, "[i]n economically backward community without a middle class and with the upper class keeping itself completely aloof from participation in the cultural life of the community, the school teachers, because of their higher literacy level ..., and the journalists because of their ability to wield the pen, can and have to play a dominant and determinant role" (1986, pp. 109-110). This proves that even these two better educated groups had restricted contact with foreign culture. Nevertheless, as we have seen above, this specific social base of modern Malay literature should not prevent us from studying its links with the cultural world of the West. Hamzah Hussin exemplifies that when a Malay author has the opportunity to become acquainted with recent trends of world writings, he proves to be attentive, appreciative and receptive to global developments. The prose of Buck appears to have produced a considerable effect upon Hamzah's novels. Thus, further exploration of the Occidental influence upon Malay authors of the 20th century will enrich our understanding of the history of Malaysian literature and bring about significant corrections and additions. 


\section{REFERENCES}

Abdul Rahman al-Ahmadi. (1987). Perancis dalam sastera Melayu moden in Sastera Melayu dan Tradisi Kosmopolitan. Kertas Kerja Hari Sastera '85. Kuala Lumpur: Dewan Bahasa dan Pustaka.

Ariffin. (1964). Hindun Sa-orang Murid Yang Miskin in Rintisan. Antoloji Cherita Pendek Melayu sa-belum Perang Dunia Kedua. Kuala Lumpur: Dewan Bahasa dan Pustaka.

Athi Sivan Mariappan. (1997). Hamzah Hussin. Sekitar pemikiran seni untuk seni. Bangi: Penerbit Universiti Kebangsaan Malaysia.

Bezruk Yu.L. (1997). Tvorchestvo Pearl Buck 1920-kh - 1930-kh godov. Zhanr, stil', metod. (Writing of Pearl Buck in 1920s - 1930s. Genre, style, method). Synopsis of a PhD. Thesis. Moscow.

Braginsky, Vladimir. (2004). The heritage of traditional Malay literature. A historical survey of genres, writings and literary views. Leiden: KITLV Press.

Buck, Pearl S. (1935). A house divided. London: Methuen and Co Ltd.

Buck, Pearl S. (1947). The good earth. London and Paris: The Albatross Group.

Buck, Pearl S. (1951). Sons. London: Methuen and Co Ltd.

Elizatul Natasyah Kamaruddin, Mohd. Zariat Abdul Rani. (2017). Wanita menurut taklif: Satu analisa terhadap watak Fatimah dalam cerpen "Perempuan Gusti" dan "Fatimah Kahwin" Karya Hamzah Hussin. MANU, 25, 23-47.

Gao, Xiongya. (2000). Pearl S.Buck's Chinese Women Characters. Selinsgrove - London: Susquehanna University Press - Associated University Presses.

Hamzah. (1997). Diwawancarai Haji Abd. Rahman Mohd. Yusof. In Ahmad Kamal Abdullah, Zaiton Ajamain (Eds.). Jambak 3. Proses kreatifpengarang Melayu. Kuala Lumpur: Dewan Bahasa dan Pustaka.

Hamzah. (1998). Novel-novel Hamzah. In S. Othman Kelantan (Ed.). Kuala Lumpur: Dewan Bahasa dan Pustaka.

Kukushkina Ye.S. (2017). "Podobno sochineniyam Shekspira": u istokov dramaturgii Malayzii ("Just like Shakespeare's oevre": at the onset of Malaysian dramaturgy). Filologicheskie nauki. Voprosy teorii I praktiki. Tambov: Gramota, 3:69, Part 2, 43-39.

Mohamad Raezi Ismail. (1994). Hamzah Hussin. Tokoh Budayawan Melayu. Terbitan Tak Berkala. Dunia Melayu N18. Bangi, Institut Alam dan Tamadun Melayu: Universiti Kebangsaan Malaysia.

Mohamad Saleeh Rahamad, Mohamad Mokhtar Abu Hassan. (2009). Pengaruh Barat dalam persuratan Melayu awal di Malaysia. Makalah dibentangkan dalam Konferensi Internasional Kesusasteraan XX, Himpunan SarjanaKesusasteraan Indonesia (HISKI) di Universitas Pendidikan Indonesia, Bandung, Indonesia, pada 5-7 Ogos 2009.

Mohd. Thani Ahmad, Sarah Sadon, Suhaimi Haji Muhammad. (1988). Wajah. 
biografi penulis. Kuala Lumpur: Dewan Bahasa dan Pustaka.

Muhammad Haji Salleh. (1981). Konsep Sasterawan ASAS 50 in Warisan ASAS 50. Kumpulan Kertas Kerja Ceramah dan Bengkel "ASAS 50 dan Sastera Melayu Moden". Kuala Lumpur: Dewan Bahasa dan Pustaka.

Nurul Farhana Low Bt Abdullah. (2012). The politics of Shakespeare translation and publication in Malaya. Traduçao en Revista 12, 39-60.

Nurul Farhana Low bt Abdullah. (2009). Bangsawan Shakespeare in colonial Malaya. In Huang, Alexander S.Y. and Ross, Charles S. (Eds.). Shakespeare in Hollywood, Asia and Cyberspace. West Lafayette, Indiana: Purdue University Press.

Othman Kelantan, S. (1998). Kata Pengantar in Novel-novel Hamzah. In S.Othman Kelantan (Ed.). Kuala Lumpur: Dewan Bahasa dan Pustaka.

Roff, William. (1974). The Mystery of the First Malay Novel (and who was Rokambul?). Bijdragen tot de Taal-, Land- en Volkenkunde, 130, 350-464.

Roff, William R. (1994). The origins of Malay nationalism. Kuala Lumpur: Oxford University Press.

Sejarah Kesusasteraan Melayu. Siri Lestari Sastera. (2006). Kuala Lumpur: Dewan Bahasa dan Pustaka.

Shaffer, Robert. (2016). Feminist Fiction in "Non-Feminist" Age: Pearl S.Buck on Asian and American Women, 1930-1963. The Journal of Transnational American Studies, 7(1), 1-26.

Siti Meriam Yaacob. (2010). Wanita dalam karya Hamzah Hussin dari perspektif kritikan feminis. Pulau Pinang: Penerbit Universiti Sains Malaysia. .

Tan Chin Kwang. (1986). The "Missing Link" in modern Malay literary history: A study of the influence of social and educational backgrounds on literary development. Archipel, 31(1), 97-115.

Ungku Maimunah Mohd. Tahir. (1994). OT Dussek and Modern Malay Literature in Tenggara. Journal of Southeast Asian Literature, 33, 68-78.

Warnk, Holger. (2007). The Role of Translations in the Development of Modern Malay Literature, 1850-1950. Journal of the Malaysian Branch of the Royal Asiatic Society, 80, 1:292, 91-113.

Warnk, Holger. (2011). Faust does Nusantara in lost times and untold tales from the Malay world. Ed. J. van der Putten \& M. Kilcline Cody. Singapore: NUS Press.

Winstedt R.O. (1969). A history of classical Malay literature. Kuala Lumpur. Oxford University Press.

Received: 13 March 2019

Accepted: 30 May 2019 